\title{
Local Population's Knowledge And Perceptions On The Biodiversity And Conservation Status Of Land Snails In The Region Of Lamto Reserve At The Centre Of Ivory Coast
}

\author{
Konan Pacôme Pokou \\ Training and Research Unit of Natural Sciences, Nangui Abrogoua \\ University, Ivory Coast \\ Nygblé Angèle Sika Piba
}

Lecturer, Training and Research Unit of Natural Sciences, Nangui Abrogoua

University, Ivory Coast

N'Golo Abdoulaye Kone

Assistant Lecturer, Training and Research Unit of Natural Sciences, Nangui Abrogoua University, Ivory Coast

\section{Abel Valery Bosso}

Training and Research Unit of Natural Sciences, Nangui Abrogoua

University, Ivory Coast

Doi:10.19044/esj.2021.v17n25p241

Submitted: 24 May 2021

Accepted: 01 July 2021

Published: 31 July 2021
Copyright 2021 Author(s)

Under Creative Commons BY-NC-ND 4.0 OPEN ACCESS

Cite As:

Pokou K.P., Sika Piba N.A., Kone N’G. A. \& Bosso A.V. (2021). Local Population's Knowledge And Perceptions On The Biodiversity And Conservation Status Of Land Snails In The Region Of Lamto Reserve At The Centre Of Ivory Coast. European Scientific Journal, ESJ, 17(25), 241.

https://doi.org/10.19044/esj.2021.v17n25p241

\section{Abstract}

Local population can play an important role in the sustainable management of biodiversity in protected area. This paper focuses on investigating local population's knowledge and perceptions on land snail's biodiversity and conservation status, by (1) testing their ability to recognize different species of land snails, (2) examining the factors involved in the reduction of land snail's biodiversity, and (3) collecting their points of view on land snail's biodiversity conservation status. Two hundred and sixty (260) people from four villages around Lamto Reserve were interviewed using structured questionnaire with six land snails supporting photos (three macro 
snails and three micro snails). The results showed that all the respondents had at least once seen the macro snails selected. More than $78 \%$ were able to recognize them without the pictures and more than $88 \%$ with the pictures. More than $85 \%$ of respondents had at least once seen the selected micro snails. Only less than $25 \%$ were able to recognize them with the pictures and less than $8 \%$ without the pictures. The considered socio-demographic variables were significantly associated with knowledge of the selected land snails. Climate change and human activities (pesticides overuse, edible land snail's consumption and selling and forest fires) have been mentioned by local population as the fundamental causes involved in land snail's biodiversity reduction in this region. The number of respondents with positive attitude (62.91\%) towards land snail's biodiversity conservation in Lamto Reserve was significantly higher than the one with negative attitude $(37.69 \%)(\mathrm{P}<0.001)$. Lamto Reserve management staff must increase the consciousness raising campaign in rural communities close to the Reserve in order to reduce the number of people who do not support biodiversity conservation.

Keywords: Land Snail Knowledge, Lamto Reserve, Local Population Perception, Biodiversity Conservation

\section{Introduction}

Ideally, protected areas should serve as cores of conservation and protection of the large biodiversity to improve human well-being by providing goods and services (Vodouhê et al., 2010; Muñoz Brenes et al., 2018). Unfortunately, previous studies highlighted the continuous and increasing reduction of biodiversity despite protected area expansion (Phalan et al., 2013; Hill et al., 2015). Adjacent population to protected areas has been considered for a long time as a potential actor of biodiversity destruction and loss of protected areas (Ikpa et al., 2009). Indeed, population develops dependence on the natural resources and the satisfaction of their needs and, generally, in illicit way induces biodiversity destruction and loss (Brandon \& Wells, 1992; Ansong \& Røskaft, 2011).

However, local population can strongly support actions for the sustainable management of biodiversity in protected areas if this management is based on their practices and knowledge, and if it takes into account a greater satisfaction of their basic needs (Wells et al., 1992). Through their traditional knowledge, local populations offer a critical source of basic environmental data for conservation and resource management (Thornton \& Scheer, 2012). In some cases, integration of local population's knowledge into conservation has been associated with enhanced species abundance (Poepoe et al., 2005) and biodiversity (Xu et al., 2005). 
Local population's knowledge of land snails is important because snails are the most reliable indicators of terrestrial biological richness and environmental conditions (Nrurinsiyah et al., 2016; Altaf et al., 2017). Numerous studies have demonstrated the significance of land snails as important links in the dynamics of natural and human-dominated ecosystems (Skeldon et al., 2007; Bloch, 2012; Douglas et al., 2013). The high land snail species diversity (Lydeard et al., 2004), their numerical abundance and ability to colonize diverse habitat types (Asuquo \& Anyanwu, 2018), have made them popular organisms to everyone (d'Ovidio et al., 2019). In rural communities, land snails are used as an important ingredient in traditional medicine (Agbelusi \& Ejidike, 1992) and the flesh is well appreciated by various populations in terms of diet (Amani et al., 2016). Some of these snails are among the important pests for agriculture (Raut \& Barker, 2002; Jayashankar et al., 2012). Thus, local people who frequently interact with snails in their local environment may develop a broader knowledge of the life histories, behavior, and seasonal changes in the composition and abundance of those snails.

Therefore, this paper focuses on investigating local population's knowledge and perceptions on land snail's biodiversity and conservation status by (1) testing their ability to recognize different species of land snails, (2) examining the factors involved in the reduction of land snail's biodiversity, and (3) collecting their points of view on land snail's biodiversity conservation status.

\section{Material and Methods Study Area}

This study was carried out in four localities around Lamto Reserve (Pacobo: 6¹1'30”N, 456’54”O; Zougoussi: 6²15'20”N, 502'51”O;

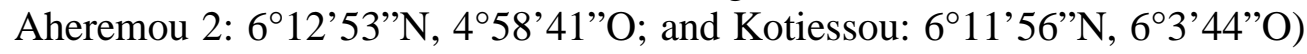
(Figure 1). These localities were selected based on their proximity to the Reserve following the directions North-South and West-East. This zone is dominated by savannah including open grassland, island forest, and gallery forest. Also, they are characterized by four seasons: a long rainy season from March to July, a short dry season in August, a short rainy season from September to October, and a long dry season from November to February (Abbadie et al., 2006). The mean annual precipitation is about $1200 \mathrm{~mm}$. Local inhabitants of this area are composed of autochthonous "Baoulé" (major ethnic group), allochtonous Malinké, and Senoufo and natives of Burkina Faso, Mali, and Guinea. Subsequently, they practice mainly shifting burned cultivation, cocoa and coffee crops, food crops (yams, plantains and rice), fishing and hunting. 


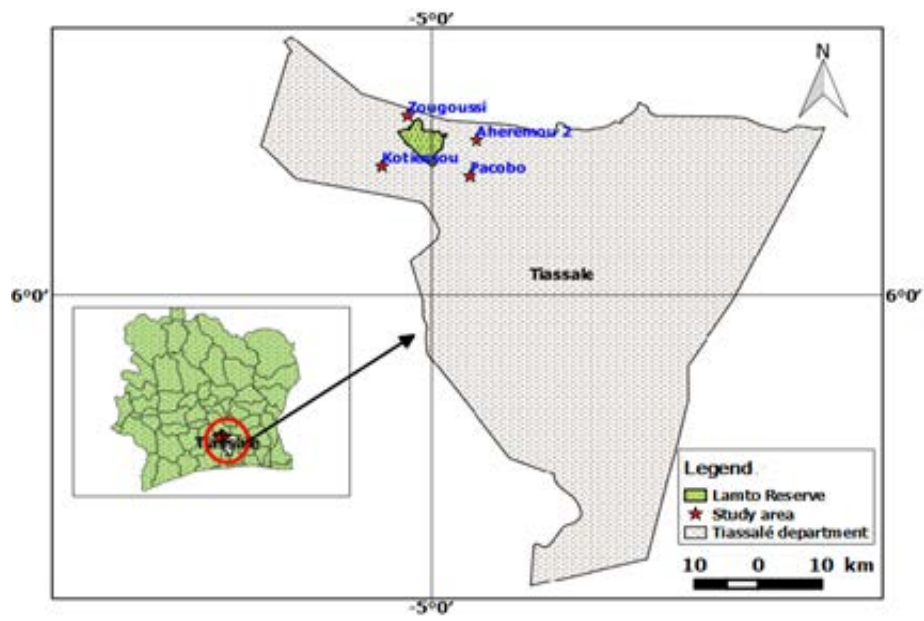

Figure 1. Map of Tiassalé division indicating Lamto Reserve and the localities of study

\section{Study Species}

A photographic support of six land snail's species among which three macro snails (diameter's size above $5 \mathrm{~mm}$ : Achatina achatina; Achatina fulica; Archachatina ventricosa) and three micro snails (diameter's size under $5 \mathrm{~mm}$ : Saphtia lamtoensis; Striosubulina striatella; Quickia concisa) was used for the interview in order to determine the extent of knowledge about these snails. These snails were common in Reserve and its rural environment and were sprung from a previous inventory study of malacofauna in Lamto Reserve and surrounding area (unpublished data). The macro snail's species were expected to be familiar to the participants while the micro snail's species is assumed to be unknown or less known to the participants because of their small size.

\section{Data Collection with Questionnaires}

In March 2019, a direct survey was conducted in these four villages. A structured questionnaire was used to interview, in isolation, each of the volunteer who was at least 18 years old. The questionnaires were prepared in French but local translator was recruited in each village to facilitate the interview when a participant could not speak French. Each questionnaire had 23 questions and included questions about the respondent's gender, age, ethnic group, educational level, his/her ability to recognize the selected snail species, the factors involved in snail biodiversity reduction, and perception about land snail biodiversity conservation in the Lamto Reserve. Pictures were used to assess the ability of local population to recognize snails (Figure 2). 


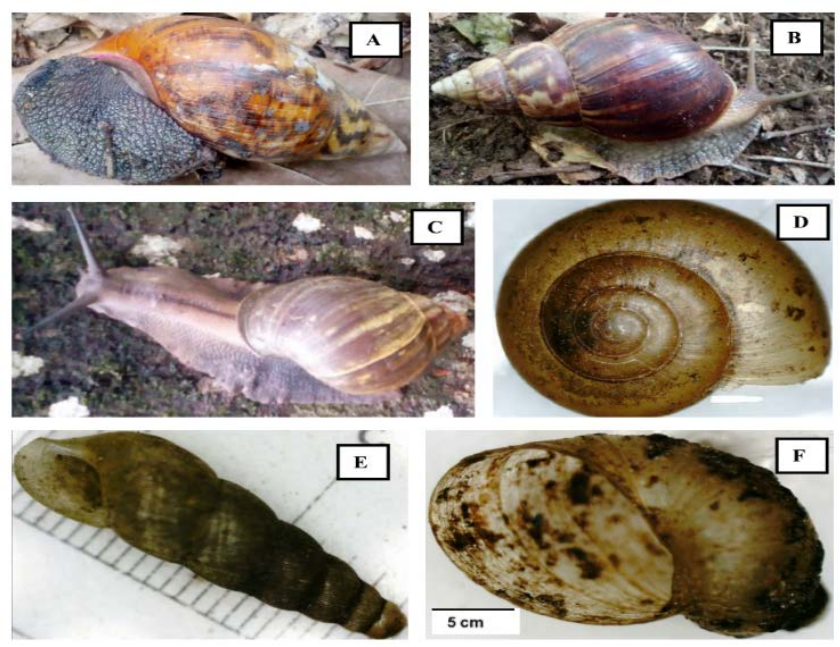

Figure 2. Pictures of selected land snails. A: Achatina achatina (Linné, 1758); B: Achatina fulica (Bowdich, 1822); C: Archachatina ventricosa (Gould, 1850); D: Saphtia lamtoensis (De Winter, 2008); E: Striosubulina striatella;(Rang, 1831); F: Quickia concisa (Morelet, 1848)

\section{Data Analysis}

Data processing and analysis were performed using the statistical software Sphinx Plus ${ }^{2}$ version 5.0. and $\mathrm{R}$ version 3.6.2. The non-parametric test (chi-squared test) was used to assess the relationships between sociodemographic variables and the respondents' knowledge about selected snails. The comparison of local population attitudes towards land snail conservation in Lamto Reserve was made using Mann-Whitney test at $\mathrm{p}=0.05$ level.

\section{Results}

\section{Socio-demographic Characteristics of the Surveyed Populations}

In total, 260 people were interviewed among them, i.e., 130 male respondents and 130 female respondents (Table 1). The highest number of respondents were recorded with age group range from 25 to 45 years old (149 respondents), with no education respondents (134 respondents), and Baoulé ethnic group respondents (203 respondents). Among localities, Aheremou 2 had the highest number of respondents (75 respondents) (Table 1 ). 
Table 1. Number of respondents according to socio-demographic variables (total number of respondents: $\mathrm{n}=260$ )

\begin{tabular}{|lll|}
\hline Socio-demographic variables & Total number of respondents \\
\hline \multirow{3}{*}{ Localities } & Pacobo & 70 \\
of study & Aheremou 2 & 75 \\
& Kotiessour & 61 \\
& Zougoussi. & 54 \\
\hline \multirow{3}{*}{ Gender } & Male & 130 \\
\hline \multirow{3}{*}{ Ages } & Female & 130 \\
& $18 \geq a g e \geq 24$ years & 39 \\
& $25 \geq$ age $\geq 45$ years & 149 \\
Educational levels & age $\geq 45$ years & 72 \\
& No education & 134 \\
& Primary school & 65 \\
& Secondary school and higher & 61 \\
\hline \multirow{3}{*}{ Ethnic groups } & Baoulé & 203 \\
& Malinké. & 4 \\
& Senoufo & 9 \\
& Burkinabé & 10 \\
& Other* & 34 \\
\hline
\end{tabular}

* Other represents another ethnic group (Ivoirian's allochtonous) living in this area

\section{Knowledge of Individual Land Snail Species}

All respondents had at least once seen the selected macro snails. More than $78 \%$ were able to recognize them without the pictures and more than $88 \%$ with the pictures (Table 2). Among the macro snail species, Achatina fulica was less known by respondents compared to Achatina achatina and Archachatina ventricosa. More than $85 \%$ of respondents had at least once seen the micro snails selected, but only less than $25 \%$ were able to recognize them with the pictures and less than $8 \%$ without the pictures (Table 2). Among these micro snail species, Saphtia lamtoensis was more familiar to respondents than Striosubulina striatella and Quickia concisa. 
Table 2. Percentage of respondents who had known the snails in question, those who had recognized them with the pictures, and those who had only seen the snails (total number of respondents: $n=260$ )

\begin{tabular}{|c|c|c|c|c|}
\hline $\begin{array}{l}\text { Localities } \\
\text { of study }\end{array}$ & Species (scientific names) & $\begin{array}{l}\text { Respondents } \\
\text { who had } \\
\text { known } \\
\text { snails } \\
\text { without } \\
\text { pictures (\%) }\end{array}$ & $\begin{array}{l}\text { Responden } \\
\text { ts who had } \\
\text { recognized } \\
\text { snails with } \\
\text { pictures } \\
(\%) \\
\end{array}$ & $\begin{array}{c}\text { Respond } \\
\text { ents who } \\
\text { had only } \\
\text { seen the } \\
\text { snails } \\
(\%) \\
\end{array}$ \\
\hline \multirow{6}{*}{ Pacobo } & Achatina achatina (Linné, 1758) * & 98.60 & 100 & 100 \\
\hline & Archachatina ventricosa (Gould, 1850) * & 97.14 & 100 & 100 \\
\hline & Achatina fulica (Bowdich, 1822) * & 80.00 & 95.71 & 100 \\
\hline & Striosubulina striatella (Rang, 1831) & 4.28 & 4.00 & 92.86 \\
\hline & Saphtia lamtoensis (De Winter, 2008) & 7.14 & 14.28 & 95.71 \\
\hline & Quickia concisa (Morelet, 1848) & 0.00 & 2.40 & 94.28 \\
\hline \multirow{6}{*}{$\begin{array}{c}\text { Aheremou } \\
2\end{array}$} & Achatina achatina (Linné, 1758) * & 100 & 100 & 100 \\
\hline & Archachatina ventricosa (Gould, 1850) * & 98.67 & 100 & 100 \\
\hline & Achatina fulica (Bowdich, 1822) * & 80.00 & 97.33 & 100 \\
\hline & Striosubulina striatella (Rang, 1831) & 0.00 & 6.67 & 90.67 \\
\hline & Saphtia lamtoensis (De Winter, 2008) & 4.00 & 14.67 & 94.67 \\
\hline & Quickia concisa (Morelet, 1848) & 0.00 & 5.33 & 88.00 \\
\hline \multirow{6}{*}{ Kotiessou } & Achatina achatina (Linné, 1758) * & 100 & 100 & 100 \\
\hline & Archachatina ventricosa (Gould, 1850) * & 98.40 & 100 & 100 \\
\hline & Achatina fulica (Bowdich, 1822) * & 78.70 & 88.50 & 100 \\
\hline & Striosubulina striatella (Rang, 1831) & 3.28 & 14.75 & 85.24 \\
\hline & Saphtia lamtoensis (De Winter, 2008) & 6.60 & 22.95 & 95.08 \\
\hline & Quickia concisa (Morelet, 1848) & 0.00 & 6.56 & 88.52 \\
\hline \multirow{6}{*}{ Zougoussi } & Achatina achatina (Linné, 1758) * & 100 & 100 & 100 \\
\hline & Archachatina ventricosa (Gould, 1850) * & 100 & 100 & 100 \\
\hline & Achatina fulica (Bowdich, 1822) * & 83.30 & 96.50 & 100 \\
\hline & Striosubulina striatella (Rang, 1831) & 0.00 & 22.22 & 85.18 \\
\hline & Saphtia lamtoensis (De Winter, 2008) & 7.41 & 24.07 & 96.30 \\
\hline & Quickia concisa (Morelet, 1848) & 0.00 & 12.96 & 90.94 \\
\hline
\end{tabular}

The specices with asterix are macro snails and those without asterix are micro snails

\section{Influence of Socio-demographic Variables on Knowledge of Land Snails}

The variability of the visited localities had a significant influence on the knowledge of the selected snails $\left(\chi^{2}=45.11 ; \mathrm{dl}=6\right.$; $\left.\mathrm{p}<0.001\right)$. Zougoussi had the highest proportion of respondents with perfect knowledge of snails (59.26\%), while Pacobo had the lowest proportion (21.43\%). However, Pacobo recorded the lowest proportion of respondents with poor knowledge (7.14\%), while the highest (24.00\%) was obtained in Aheremou 2 (Table 3).

The gender of respondents had a significant influence on knowledge of selected snails $\left(\chi^{2}=10.504 ; \mathrm{dl}=2 ; \mathrm{p}<0.010\right)$. Among male respondents, $43.08 \%$ had perfect knowledge against $29.23 \%$ of female respondents. Only $9.23 \%$ of male respondents had a poor knowledge of snails against $22.31 \%$ of the female respondents (Table 3). 
The age of respondents had also a significant influence on knowledge of selected snails $\left(\chi^{2}=50.857 ; \mathrm{dl}=4 ; \mathrm{p}<0.001\right)$. None of the younger respondents ( $18 \geq$ age $\geq 24$ years old) had perfect knowledge of snails, while older respondents (age $\geq 45$ years old) had the highest proportion (50\%). Moreover, among the respondents who had poor knowledge of snails, young respondents were the most represented (48.72\%) in contrast to the older respondents (8.33\%) (Table 3).

The educational level of respondents had a significant influence on knowledge of selected snails $\left(\chi^{2}=37.937 ; \mathrm{dl}=4 ; \mathrm{p}<0.001\right)$. The respondents with primary school level had the highest perfect knowledge (50.77\%), while no education respondents recorded the lowest (30.60\%). However, no education respondents were the least represented among those with a poor knowledge of snails (6.72\%) (Table 3).

The ethnic group of respondents had a significant influence on knowledge of selected snails $\left(\chi^{2}=31.265 ; \mathrm{dl}=8 ; \mathrm{p}<0.001\right)$. Baoulé ethnic group's respondents had the highest perfect knowledge (41.38\%), while no respondent from Burkina Faso had a perfect knowledge (Table 3). Respondents from Burkina Faso were the most numerous among those with poor knowledge of snails (70\%) (Table 3).

Table 3. Level of knowledge of selected snails according to socio-demographic variables

\begin{tabular}{|c|c|c|c|c|c|}
\hline \multicolumn{2}{|c|}{ Socio-demographic variables } & $\begin{array}{c}\text { Perfect } \\
\text { knowledge } \\
\text { (5-6 snails } \\
\text { known) } \\
(\%)\end{array}$ & $\begin{array}{c}\text { Good } \\
\text { knowledge } \\
\text { (3-4 snails } \\
\text { known) } \\
(\%)\end{array}$ & $\begin{array}{c}\text { Poor } \\
\text { knowledge } \\
(0-2 \text { snails } \\
\text { known) } \\
(\%)\end{array}$ & $\begin{array}{c}\text { Total } \\
\text { numbe } \\
\text { r of } \\
\text { respon } \\
\text { dents }\end{array}$ \\
\hline \multirow{4}{*}{$\begin{array}{c}\text { Localitie } \\
\text { s of } \\
\text { study }\end{array}$} & Pacobo & 21.43 & 71.43 & 7.14 & 70 \\
\hline & Aheremou 2 & 26.67 & 49.33 & 24.00 & 75 \\
\hline & Kotiessou & 44.26 & 39.34 & 16.40 & 61 \\
\hline & Zougoussi & 59.26 & 25.92 & 14.82 & 54 \\
\hline \multirow[t]{2}{*}{ Gender } & Male & 43.08 & 47.69 & 9.23 & 130 \\
\hline & Female & 29.23 & 48.46 & 22.31 & 130 \\
\hline \multirow{3}{*}{ Ages } & $18 \geq$ age $\geq 24$ years & 0.00 & 51.28 & 48.72 & 39 \\
\hline & $25 \geq$ age $\geq 45$ years & 38.93 & 50.33 & 10.74 & 149 \\
\hline & age $\geq 45$ years & 50.00 & 41.67 & 8.33 & 72 \\
\hline \multirow{3}{*}{$\begin{array}{c}\text { Educational } \\
\text { levels }\end{array}$} & No education & 30.60 & 62.68 & 6.72 & 134 \\
\hline & Primary school & 50.77 & 32.31 & 16.92 & 65 \\
\hline & $\begin{array}{c}\text { Secondary school and } \\
\text { higher }\end{array}$ & 32.79 & 32.79 & 34.42 & 61 \\
\hline \multirow{5}{*}{$\begin{array}{l}\text { Ethnic } \\
\text { groups }\end{array}$} & Baoulé & 41.38 & 45.81 & 12.81 & 203 \\
\hline & Malinké & 25.00 & 50.00 & 25.00 & 4 \\
\hline & Senoufo & 22.22 & 55.56 & 22.22 & 9 \\
\hline & Burkinabé & 0.00 & 30.00 & 70.00 & 10 \\
\hline & Other* & 20.59 & 64.70 & 14.71 & 34 \\
\hline
\end{tabular}

* Other represents another ethnic group (Ivoirian's allochtonous) living in this area 


\section{Perception of Local Population on the Causes of Land Snail's Biodiversity Reduction}

Globally, 191 respondents (73.46\%) had quoted human activities (pesticide overuse, edible land snail's consumption and selling and forest fires) as a fundamental cause of land snail's biodiversity reduction, while 111 respondents (42.69\%) had mentioned the effect of climate change. Only 2 respondents $(0.77 \%)$ had highlighted other cause such as predation.

According to the visited localities, Kotiessou (82\%) and Zougoussi (61.10\%) recorded the highest proportion of respondents who had mentioned respectively human activities and climate change as the major causes of land snail's biodiversity reduction (Figure 3). Beyond human activities and climate change listed in all localities, other cause (predation) had been stressed in Aheremou 2 and Pacobo in roughly the same proportion (respectively 1.3\% and $1.4 \%$ ) (Figure 3).

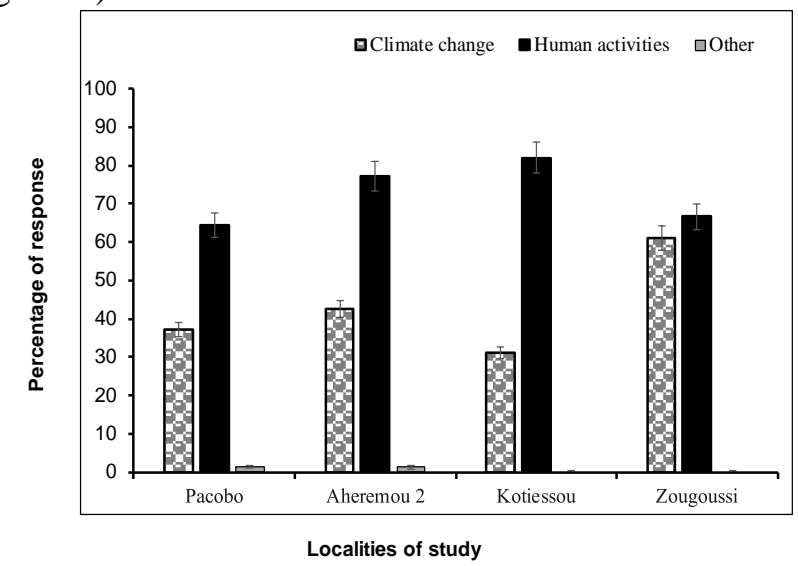

Figure 3. Percentage response patterns from respondents across localities of study regarding the causes of land snail's biodiversity reduction

\section{Perceptions of Local Population towards Land Snail's Biodiversity Conservation in Lamto Reserve}

Overall, 98 respondents (37.69\%) were unfavorable to snail conservation in Lamto Reserve while 162 respondents (62.31\%) were favorable. The difference between respondents with positive attitude (favorable) to snail's conservation and those with negative attitude (unfavorable) was significant (Mann-Whitney test; $\mathrm{p}<0.001$ ). The respondents in favor of snail conservation are those who give their approval to respect the conservation measures in force in the Lamto Reserve. Thus, according to the visited localities, the highest proportion of respondents in favor of snail conservation was obtained in Zougoussi (81.48\%) and the lowest in Kotiessou (44.26\%) (Figure 4). 


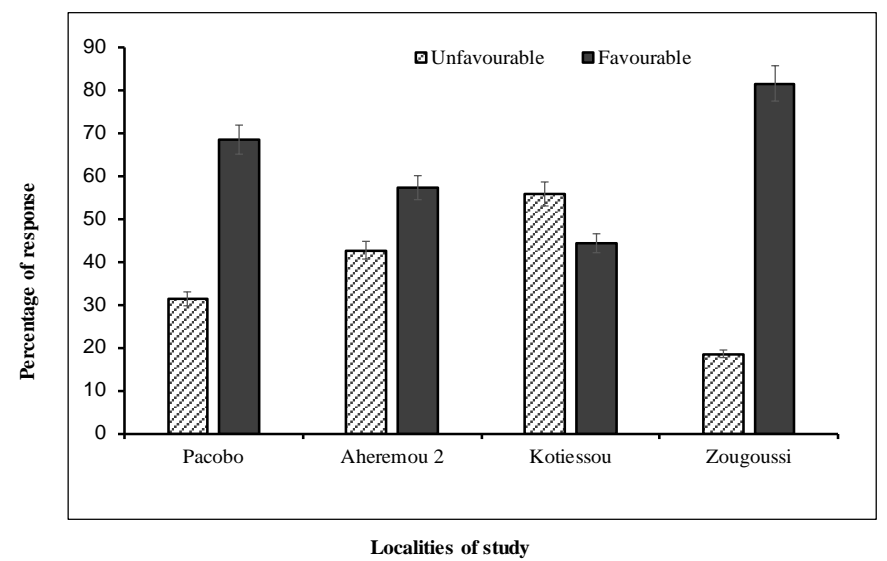

Figure 4. Percentage response patterns from respondents across localities of study regarding the respect of land snail's conservation measures in Lamto Reserve

\section{Discussion}

\section{Knowledge of Individual Land Snail Species}

Overall, selected land snails were well known by respondents. This result could be due to the distribution of these species which are common and widespread in variety of habitats including open grassland, wooded grassland, fallow, and forest (Idohou et al., 2013; Dar et al., 2017). Difference in knowledge between macro and micro snails could be linked to their size. Indeed, because of their large size, macro snails attract more attention from respondents compared to micro snails usually found in litter (Douglas et al., 2013). Among macro snails, Achatina achatina and Archachatina ventricosa (edible snails) were widely known certainly because they are well appreciated in human diet in Côte d'Ivoire (Dosso et al., 2007; Amani et al., 2016).

The knowledge of selected snails was significantly influenced by the variability of study localities. A contrary result was obtained by Ansong and Røskaft (2011) around Subri Forest Reserve of Ghana. The highest number of respondents with perfect knowledge of snails was obtained in Zougoussi, while the lowest number was recorded in Pacobo. This could be due to a difference in the development stage of these localities. Indeed, compared to Zougoussi, Pacobo had a relatively more advanced stage of development. In Zougoussi, almost all the populations were farmers. As a result, they could have more contact with snails. This couldn't be the case of Pacobo with varied sectors of activities (Boguhe et al., 2011).

The male respondents recorded the highest perfect knowledge of snails compared to the female respondents. The different roles that exist between men and women particularly in most of Baoulé farmer's communities could contribute to men's ability to know snails. Indeed, although women support significantly their husbands in field activities (Ruf, 2016), the men spent more time wandering in forests while women were in charge of housework (De 
Rouw, 1991). No younger respondents had a perfect knowledge of selected snails, while the older respondents recorded the largest number of people. This could be due to the fact that young respondents were less experienced compared to older. According to Senanayake (2006), local knowledge results from experience and this knowledge is building on the experience of the past and present generation. Respondents with primary school level had the highest perfect knowledge of selected snails. A contrary result was obtained by Mmassy and Røskaft (2013) in Tanzania. Baoulé ethnic group’s respondents had the highest perfect knowledge of selected snails and the poorest knowledge was recorded with the respondents from Burkina Faso. This result could be due to the activities, food habit, and the civilization of these groups. Indeed, the Baoulé ethnic groups are generally farmers in the villages; they spend more time in forest and appreciate very well the flesh of snails in diet (Amani et al., 2016). Such a lifestyle might improve their opportunities to see and become familiar to snail's species. This couldn't be the case of respondents from Burkina Faso who were mostly cattle breeders (FAO, 2018) and perceive edible snails as totem.

\section{Perceptions of Local Population on the Causes of Land Snail's Biodiversity Reduction and on their Conservation Status in Lamto Reserve}

This study disclosed that local population living around Lamto Reserve was cognizant of the causes of land snail's biodiversity loss. Climate change and human activities were identified by respondents as the major causes of land snail's biodiversity reduction. Similar results were reported in scientific publications among others, like Chiba and Cowie (2016) who showed that climate change and habitat loss due to human activities such as deforestation, cultivation, mineral extraction, and urbanization constitute the main causes of land snail's extinction on oceanic islands. In addition, Nicolai and Ansart (2017) underlined that human-driven habitat loss through intensified urbanization, agriculture, and forestry dramatically increased the impact of climate change and endangers the species living in restricted habitat and with low dispersal such as land snails. Finally, excessive and misuse of pesticides result in environment contamination causing biodiversity loss particularly land snails (Nkontcheu et al., 2017; Baroudi et al., 2020).

About $38 \%$ of all the respondents had negative perception of land snail's biodiversity conservation in Lamto Reserve. Indeed, most of local populations living around Lamto Reserve are farmers, fishermen and hunters and the Reserve management law prohibits their access to such activities. This may generate a strong and negative opinion on the management and the conservation of biodiversity as reported by Vodouhê et al. (2010). Besides, they complain that Reserve establishment evicted local population from their 
former areas and the Reserve management policy doesn't take into account the development of their localities through the implementation of project and infrastructures such as construction of schools and hospitals. This perception corroborates with the work done by Torri (2011). These people believe that they receive no benefit from the Reserve and often defy the ban on hunting and resource extraction. When they are apprehended by the Army in charge of protecting Reserve and enforcing management laws, they are subjected to the rigours of the law and this reinforces their negative perception of the Reserve's management. This position wasn't shared by the majority of respondents to whom conservation of biodiversity in Reserve is important because of endangered animal and plant species that are well conserved in the Reserve.

\section{Conclusion}

At the end of this study, it can be concluded that the majority of respondents had a good knowledge of the selected land snails (with a focus on macro snails) and the causes of their biodiversity reduction. However, given that all the selected snails were common in the Lamto Reserve and its surrounded rural area, the local population's knowledge in some particular young male and female persons was poor for certain species (micro snails in the majority). The considered socio-demographic variables were significantly associated with knowledge of the selected land snails. The majority of respondents were favorable towards land snail biodiversity conservation in Lamto Reserve. In others words, they hold positive attitudes towards Reserve management.

We further recommend to the Lamto Reserve management staff to pursue collaboration with the rural communities close to the Reserve for best management. This collaboration based on the negotiations, exchanges, and awareness rising could reduce the number of people who do not support Reserve biodiversity conservation.

\section{Acknowledgements}

The research team is grateful to Mr. Kouassi Ago, Mr. N’Goran Yao, Mr. Yao Kouassi, and Mr. Kokora Jules Djezou respectively chief of Pacobo, Aheremou 2, Zougoussi and Kotiessou for their cordial welcome. Special thanks to Mr. Kouakou Pierre Claver Kouassi, Mr. Kouakou Jean Eudes Kouassi, Mr. Sylvain Kouassi, and Mr. Konan David Kra for the translation of messages from local language to French and vice versa.

\section{References:}

1. Abbadie, L., Gignoux, J., Le Roux, X. and Lepage, M. (2006). Lamto: structure, functioning and dynamics of a savanna ecosystem. Springer Verlag New York. 412p. 
2. Agbelusi, E.A. and Ejidike, B.N. (1992). Utilization of the Giant African Land Snail, Archachatina marginata in the humid area of Nigeria. Journal of Tropical Agriculture 69 (1): 88-92.

3. Altaf, J., Qureshi, N.A. and Siddiqui, M.J.I. (2017). Terrestrial snails as bioindicators of environmental degradation. Journal of Biodiversity and Environmental Sciences 10 (1): 253-264.

4. Amani, N.S.C., Karamoko, M., Adou, C.F.D. and Otchoumou, A. (2016). Impact of the gathering pressure on edible snail's population of a classified forest in the South of Côte d'Ivoire. International Journal of Natural Resources Ecology and Management 1 (2): 11-19.

5. Ansong, M. and Røskaft, E. (2011). Determinants of attitudes of primary stakeholders towards forest conservation management: a case study of Subri Forest Reserve, Ghana. International Journal of Biodiversity Science, Ecosystem Services \& Management 7 (2): 98107.

6. Asuquo, F.E. and Anyanwu, T.C. (2018). Mollusk Response to Anthropogenic Impacts: An Example from Cross River Estuary, South Eastern Nigeria. Journal of Earth Science and Climatic Change 9 (5): 473. Doi: 10.4172/2157-7617.1000473.

7. Baroudi, F., Al Alam, J., Fajloun, Z. and Millet, M. (2020). Snail as sentinel organism for monitoring the environmental pollution; a review. Ecological Indicators $113: 106240$.

Doi:10.1016/j.ecolind.2020.106240.

8. Bloch, C.P. (2012). Why Snails? How Gastropods Improve Our Understanding of Ecological Disturbance. Bridgewater Review 31 (2): 8-13.

9. Boguhe, G.F., Goore Bi, G., N’Zi, K.G., Yao, S.S., Kouamelan, E.P. and Kouassi, N.J. (2011). Premières données sur la pêche crevettière du fleuve Bandama (Côte d'Ivoire) : Acteurs et Engins de pêche. Sciences \& Nature 8 (1): 107-118.

10. Brandon, K.E. and Wells, M. (1992). Planning for people and Parks: Design dilemmas. World development 20 (4): 557-570.

11. Chiba, S. and Cowie, R.H. (2016). Evolution and Extinction of Land Snails on Oceanic Islands. Annual Review of Ecology Evolution and Systematics 47: 123-141.

12. Dar, M.A., Pawar, K.D. and Pandit, R.S. (2017). Gut Microbiome Analysis of Snails: A Biotechnological Approach. Intech open Chapter 9, 30p.

13. Douglas, D.D., Brown, D.R. and Pederson, N. (2013). Land snail diversity can reflect degrees of anthropogenic disturbance. Ecosphere 4 (2): 28. Doi.org/10.1890/ES12-00361.1. 
14. d'Ovidio, D., Nermut, J., Adami, C. and Santoro, M. (2019). Occurrence of Rhabditid Nematodes in the Pet Giant African Land Snails (Achatina fulica). Frontiers in Veterinary Science 6 (88): 1-5.

15. Dosso, A., Kouassi, K.D. and Otchoumou A. (2007). Effet de l'alimentation sur les performances biologiques chez l'escargot géant africain: Archachatina ventricosa (Gould, 1850) en élevage hors sol. Livestock Research for Rural Development 19 (5): 16-20.

16. FAO (2018). Livestock production systems spotlight Burkina Faso: Cattle and poultry sectors. 9p.

17. Hill, R., Miller, C., Newell, B., Dunlop M. and Gordon I.J. (2015). Why biodiversity declines as protected areas increase: the effect of the power of governance regimes on sustainable landscapes. Sustain Science 10: 357-369.

18. Idohou, R., Djagoun, C.A.M.S., Kassa, B., Assogbadjo, A.E. and Codjia, J.T.C. (2013). Soil factors affecting density of three giant land snail species in different habitats of Dassa-Zoume district (Central Benin). QScience Connect 31:1-10.

19. Ikpa, T.F., Dera, B.A. and Jande, J.A. (2009). Biodiversity conservation: why local inhabitants destroy habitat in protected areas. Science World Journal 4 (4): 22-27.

20. Jayashankar, M., Aravind, N.A. and Reddy M.S. (2012). Distribution of pestiferous terrestrial molluscs in bangalore region, karnataka. Biodiversity and Taxonomy 7: 55-60.

21. Lydeard, C., Cowie, R.H., Ponder, W.F., Bogan, A.E., Bouchet, P., Clark, S.A., Cummings, K.S., Frest, T.J., Gargominy, O., Herbert, D.G., Hershler, R., Perez, K.E., Roth, B., Seddon, M., Strong, E.E. and Thompson, F.G. (2004). The Global Decline of Non-marine Molluscs. BioScience 54: 321-330.

22. Mmassy, E.C. and Røskaft, E. (2013). Knowledge of birds of conservation interest among the people living close to protected areas in Serengeti, Northern Tanzania. International Journal of Biodiversity Science, Ecosystem Services \& Management 9 (2):114-22.

23. Muñoz Brenes, C.L., Jones, K.W., Schlesinger, P., Robalino, J. and Vierling, L. (2018). The impact of protected area governance and management capacity on ecosystem function in Central America. PLoS ONE 13 (10): e0205964.

Doi.org/10.1371/journal.pone.0205964.

24. Nicolai, A. and Ansart, A. (2017). Conservation at a slow pace: terrestrial gastropods facing fast-changing climate. Conservation Physiology 5 (1): cox007. Doi:10.1093/conphys/cox007. 
25. Nkontcheu, D.B.K., Fai, P.B.A., Taboue, G.C.T., Tchamadeu, N.N., Ngealekeleoh, F. and Mbida, M. (2017). Assessment of Chemical Pollution With Routine Pesticides Using PRIMET, a Pesticide Risk Model in the Benoe Stream in the South-West Region of Cameroon. European Scientific Journal 13 (30): 153-172.

Doi: 10.19044/esj.2017.v13n30p153.

26. Nrurinsiyah, A.S., Fauzia, H., Hennig, C. and Hausdorf, B. (2016). Native and introduced land snail species as ecological indicators in different land use types in Java. Ecological indicators 70: 557-565.

27. Phalan, B., Bertzky, M., Butchart, S.H.M., Donald, P.F., Scharlemann, J.P.W., Stattersfield, A.J. and Balmford, A. (2013). Crop expansion and conservation priorities in tropical countries. PLoS One 8: e51759.

28. Poepoe, K.K., Bartram, P.K. and Friedlander, A.M. (2005). The use of traditional knowledge in the contemporary management of a Hawaiian community's marine resources. In Fishers' knowledge in fisheries science and management. Coastal Management Source-books, ed. Haggan, N., Neis, B., and Baird, I.G., 4:119-143. Paris: UNESCO Publishing.

29. Raut, S.K. and Barker, G.M. (2002). Achatina fulica Bowdich and other Achatinidae as pests in Tropical Agriculture. In: Barker, G.M. ed., Molluscs as Crop Pests, CAB International, pp 55-114.

30. Ruf, F. (2016). <<Une femme en Côte d'Ivoire, une femme au Burkina Faso >>: changement écologique et social autour du cacao et de l'anacarde. Eco-Geography 37: 1-23.

31. Senanayake, S.G.J.N. (2006). Indigenous knowledge as a key to sustainable development. The Journal of Agricultural Sciences 2 (1): 87-94.

32. Skeldon, M.A., Vadeboncoeur, M.A., Hamburg, S.P. and Blum, J.D. (2007). Terrestrial gastropod responses to an ecosystem-level calcium manipulation in a northern hardwood forest. Canadian Journal of Zoology 85: 994-1007.

33. Thornton, T.F. and Scheer, A.M. (2012). Collaborative engagement of local and traditional knowledge and science in marine environments: A review. Ecological Society 17 (3):8.

34. Torri, M.C. (2011). Conservation, relocation and the social consequences of conservation policies in protected areas: Case study of Sariska Tiger Reserve, India. Conservation and Society 9 (1): 5464.

35. Vodouhê, F.G., Coulibaly, O., Adégbidi, A. and Sinsin, B. (2010). Community perception of biodiversity conservation within protected areas in Benin. Forest Policy and Economics 12: 505-512. 
36. Wells, M., Brandon, K. and with Hannah, L. (1992). People and Parks: Linking Protected Area Management with Local Communities. World Bank, Washington, DC.

37. Xu, J., Ma, E., Tashi, D., Fu, Y., Lu, Z. and Melick, D. (2005). Integrating sacred knowledge for conservation: Cultures and landscapes in southwest China. Ecology and Society 10 (2): 7. Doi:10.5751/es-01413-100207. 